\title{
Effects of natural nitrite source from Swiss chard on quality characteristics of cured pork loin
}

\author{
Tae-Kyung Kim, Ko-Eun Hwang'², Dong-Heon Song², Youn-Kyung Ham², \\ Young-Boong Kim ${ }^{1}$, Hyun-Dong Paik ${ }^{2}$, and Yun-Sang Choi ${ }^{1}$ *
}

\begin{abstract}
* Corresponding Author: Yun-Sang Choi Tel: +82-63-219-9387, Fax: +82-63-219-9076 E-mail: kcys0517@kfri.re.kr
\end{abstract}

${ }^{1}$ Research Group of Food Processing, Korean Food Research Institute, Wanju 55365, Korea 2 Department of Food Science and Biotechnology of Animal Resources, Konkuk University, Seoul 05029, Korea

ORCID

Tae-Kyung Kim

https://orcid.org/0000-0002-6349-4314 Ko-Eun Hwang

https://orcid.org/0000-0003-2718-560X Dong-Heon Song

https://orcid.org/0000-0002-4670-3321

Youn-Kyung Ham

https://orcid.org/0000-0002-5659-5256

Young-Boong Kim

https://orcid.org/0000-0001-8441-198X

Hyun-Dong Paik

https://orcid.org/0000-0001-9891-7703

Yun-Sang Choi

https://orcid.org/0000-0001-8060-6237

Submitted Feb 8, 2019; Revised Apr 8, 2019; Accepted Apr 17, 2019
Objective: This study was conducted to evaluate quality characteristics of cured pork loin with natural nitrite source from Swiss chard.

Methods: Pork loin was cured in brine and the ratio of water and fermented Swiss chard (FSC) solution in the brine was changed by 4:0 (control), 3:1 (T1), 1:1 (T2), 1:3 (T3), 0:4 (T4), and pickled samples with $0.012 \%$ sodium nitrite (PC, positive control) and nitrite free brine (NC, negative control) were considered as the control.

Results: The $\mathrm{pH}$ values of cured pork loins with FSC were decreased with increasing addition level of FSC. Cooking loss was not significantly different among all treatments. T4 had the lowest value in moisture content and lightness value and the highest value in curing efficiency. The redness value of T4 was not significantly different from that of PC in raw. After cooking, however, it was higher than that of PC. The yellowness value of cured pork loin added with FSC was increased with increasing level of FSC. Volatile basic nitrogen content of cured pork loin added with FSC was higher than PC and NC. Thiobarbituric acid reactive substance value of cured pork loin added with FSC was decreased with increasing FSC level. Residual nitrite level and shear force were increased with increasing FSC level. In the sensory evaluation, sensory score for flavor, off-flavor, chewiness, juiciness, and overall acceptability were not significantly different among all treatments. However, sensory score for color was increased when the concentration of FSC added to pork loin was increased.

Conclusion: The FSC solution had a positive effect on redness and lipid oxidation. As shown by the results in protein deterioration and sensory, Swiss chard can replace sodium nitrite as natural curing agent.

Keywords: Swiss Chard; Natural Nitrite; Synthetic Nitrite; Meat; Cured Pork Loin

\section{INTRODUCTION}

In the past, people have used nitrite and nitrate salts to enhance the shelf stability, flavor, antimicrobial activities, and color of meat and meat products and direct addition of sodium nitrite have been used in curing meat and meat products [1]. Nitrite can develop color and restrain toxin production of pathogenic bacteria such as Clostridium botulinum of meat and meat products. Nitrite is converted into nitric oxide which form NO-Mb and nitrosohemochrome with myoglobin which is a pinkish color [2]. Despite these advantages, It is controversial issue which is addition of nitrate and nitrite to meat products due to carcinogenic potency of nitrite by forming N-nitrosamine with amines in meat products [3]. Because of this negative effect of nitrite, the development of natural and healthy meat product have been needed. The focus on meat products has moved to "natural" meat product and the concern about chemical curing agent such as nitrite and nitrate make that consumer felt constrained to pay for natural foods with growing interest about health care. Some researchers 
have tried to search for natural alternatives of nitrite from soil, water, and plants to replace synthetic nitrite [4].

Celery powder has been used as flavor enhancer and nitrate-reducing source to produce some fermented sausages since the 1950s. When celery powder is used in the curing process, it must be incubated to convert nitrate to nitrite prior to the heating process for suitable color formation [5]. However, Ballmer-Weber et al [6] reported allergic reaction to celery using double-blind placebo-controlled food challenges with raw-celery, cooked celery and celery spice, even after heating for $76 \mathrm{~min}$ at $100^{\circ} \mathrm{C}$. Therefore, the use of celery on food needs to be watched for celery-allergic patients and celery must be substituted with non-allergenic materials.

Swiss chard (Beta vulgaris cicla) is a vegetable in the family of Chenopodiaceae. It can be cultivated easily in poor surroundings. Since 1000 B.C., Swiss chard has been used for nourishment by Mediterranean people. Swiss chard has antihypertensive and hypoglycaemic action and also possesses antioxidant components such as polyphenols, flavonoids, and vitexin [7]. According to Ninfali and Angelino [8], total phenols, flavonoids, and oxygen radical absorbance capacity of leaves of Swiss chard were $11.12 \pm 0.56 \mathrm{mg} / \mathrm{g}$ dry weight $(\mathrm{DW})$, $7.92 \pm 0.39 \mathrm{mg} / \mathrm{g}$ DW, and $192.8 \pm 9.6$ trolox equivalents $\mu \mathrm{mol} / \mathrm{g}$ DW and nitrate in plant is formed by absorbed nitrogen. The mean nitrate content in Swiss chard is 568.5 to 3,407.4 ppm [9]. Therefore, Swiss chard can be a good source of nitrate which can be converted to nitrite for natural curing. However, no study has reported the effect of pre-converted Swiss chard on cured meat.

Therefore, the objective of this study was to assess the possibility of using pre-converted Swiss chard as a source of natural nitrite for cured meat without direct addition of sodium nitrite.

\section{MATERIALS AND METHODS}

Preparing natural nitrite source from Swiss chard and the processing of cured pork loin

Freeze-dried Swiss chard powder that was obtained from local market was diluted with distilled water, and 10\% (w/v) Swiss chard solution was incubated with starter culture (S-B-61,
Bactoferm, Chr. Hansen Inc., Gainesville, FL, USA) at $37^{\circ} \mathrm{C}$ for $24 \mathrm{~h}$ and starter culture contained only Staphylococcus carnosus. Fermented Swiss chard solution (FSC, pH 5.24, Commission Internationale de l'Eclairage [CIE] L*-value, 14.05; CIE a ${ }^{*}$-value, 2.03; CIE $b^{*}$-value, 6.98; nitrite content, 322 ppm) was used immediately after incubation. Nitrite content in fermented Swiss chard was measured by diazo coupling method [10]. Formulation of cured pork loin was shown in Table 1. Fresh pork loin (M. longissimus lumborum) was obtained from a local processor postmortem $48 \mathrm{~h}$. After trimming excessive fat and connective tissue, each loin was cut into 2.54 $\mathrm{cm}$ in thickness. After pickled pork loins in $40 \%$ brine in proportion to pork loin weight, samples were tumbled with a tumbler (MKR-150C, Ruhle GmbH., Grafenhausen, Germany) for $60 \mathrm{~min}$ at $4^{\circ} \mathrm{C}$. Tumbled treatments were cured for 4 days in refrigerated room at $4^{\circ} \mathrm{C}$ [11]. After curing, cured pork loins were heated for $30 \mathrm{~min}$ at $75^{\circ} \mathrm{C}$ and cooled at room temperature $\left(25^{\circ} \mathrm{C}\right)$ for $1 \mathrm{~h}$.

\section{pH}

Homogenate of cured pork loins ( $5 \mathrm{~g}$ in $20 \mathrm{~mL}$ distilled water) on raw and cooked were used for $\mathrm{pH}$ measurement. All determinations were performed in triplicates. The $\mathrm{pH}$ meter (Model 340, Mettler-Toledo GmbH, Greifensee, Switzerland) was used for measuring.

\section{Cooking loss}

After heating for $30 \mathrm{~min}$ at $75^{\circ} \mathrm{C}$, a sample was cooled to room temperature $\left(25^{\circ} \mathrm{C}\right)$ for $1 \mathrm{~h}$. Weight difference between before and after heating was calculated into a percentage.

\section{Moisture content}

According to AOAC [12], moisture content (950.46B) of cooked samples was determined based on weight loss after $12 \mathrm{~h}$ of drying at $105^{\circ} \mathrm{C}$ in a drying oven (SW-90D, Sang Woo Scienectific Co., Bucheon, Korea).

\section{Color}

Raw and cooked cured pork loins were sliced lengthwise. The internal surface color of samples was determined immediately.

Table 1. Formulation of cured pork loin with natural nitrite source from fermented Swiss chard (FSC)

\begin{tabular}{lcccccc}
\hline \multirow{2}{*}{ Ingredients } & \multicolumn{5}{c}{ Treatments $^{\text {1) }}$} \\
\cline { 2 - 6 } & PC & NC & T1 & T2 & T3 & T4 \\
\hline Pork loin (\%) & 100 & 100 & 100 & 100 & 100 & 100 \\
Water (\%) & 40 & 40 & 30 & 20 & 10 & 0 \\
Fermented Swiss chard solution (\%) & 0 & 0 & 10 & 20 & 30 & 1.5 \\
Salt (\%) & 1.5 & 1.5 & 1.5 & 1.5 & 1.5 \\
Nitrite (ppm) & 120 & 0 & 32.2 & 64.4 & 96.6 & 128.8 \\
\hline
\end{tabular}

1) PC, positive control, 120 ppm nitrite; NC, negative control, nitrite-free; T1, FSC solution:water = 10:30; T2, FSC solution:water = 20:20; T3, FSC solution:water = 30:10; T4, FSC solution:water $=40: 0$. 
CIE $L^{*}$-value, CIE $a^{*}$-value, and CIE $b^{*}$-value values were expressed as lightness, redness, and yellowness and a colorimeter (Minolta Chroma meter CR-210, Minolta Ltd., Tokyo, Japan; illuminate $\mathrm{C}$, calibrated with a white plate, $\mathrm{CIE} \mathrm{L}^{*}$-value, 97.83; CIE $\mathrm{a}^{*}$-value, 0.43; CIE $\mathrm{b}^{\star}$-value, 1.98) was used.

\section{Curing pigments and total pigments}

Hornesey's method [13] was used to determine NO-heme (curing pigment) and total heme pigments (total pigment). Ten grams of ground sample was mixed with $80 \%(\mathrm{v} / \mathrm{v})$ acetone for $5 \mathrm{~min}$ in reduced light to obtain curing pigment concentration. After filtering the solution through Whatman No. 1 filter paper (Whatman International, Maidstone, UK), absorbance of filtrate was measured at $540 \mathrm{~nm}$ using spectrophotometer (Optizen 2120 UV plus, Mecasys Co. Ltd., Daejeon, Korea) and NO-heme concentration was calculated by multiplying absorbance by 290 . Total pigment concentration was obtained with $10 \mathrm{~g}$ minced sample and acidified $80 \%$ acetone. After mixing for $1 \mathrm{~h}$, solution was filtered through Whatman No. 1 filter paper. Absorbance of filtrate was obtained at $640 \mathrm{~nm}$ using spectrophotometer and multiplied by 680 to determine total pigment concentration. Curing efficiency is the percentage of total pigment converted to curing pigment and it could be used as index of the degree of cured color fading.

\section{Thiobarbituric acid reactive substances value}

Lipid oxidation was assessed in triplicates using the 2-thiobarbituric acid (TBA) method of Tarladgis et al [14] with minor modifications. After homogenize cooked sample with $97.5 \mathrm{~mL}$ of distilled water, a mixture was added with $2.5 \mathrm{~mL}$ of $4 \mathrm{~N} \mathrm{HCl}$ and a few drops of an antifoam agent, silicone o/w (KMK-73, Shin-Etsu Silicone Co., Ltd., Seoul, Korea) into a distillation flask. After collect $50 \mathrm{~mL}$ distillate, a well mixture of $5 \mathrm{~mL}$ of the distillate and $5 \mathrm{~mL}$ of $0.02 \mathrm{M}$ TBA in $90 \%$ acetic acid (TBA reagent) in capped tube heated in a boiling water bath at $100^{\circ} \mathrm{C}$ for $30 \mathrm{~min}$ and a blank was prepared with $5 \mathrm{~mL}$ of distilled water and $5 \mathrm{~mL}$ of TBA reagent. After cooling for $10 \mathrm{~min}$ at room temperature, the absorbance of reactant was measured at $538 \mathrm{~nm}$ with an UV/VIS spectrophotometer (Optizen 2120 UV plus, Mecasys Co. Ltd., Korea). Thiobarbituric acid reactive substances (TBARS) content was calculated from a standard curve (8 to $50 \mathrm{nmol}$ ) of malondialdehyde (MDA), freshly prepared by acidification of 1,1,3,3-tetraethoxy poppane. Reagents were obtained from Sigma (St. Louis, MO, USA). TBARS levels were expressed as MDA mg/meat $\mathrm{kg}$.

\section{Volatile basic nitrogen content}

Volatile basic nitrogen $(\mathrm{VBN})$ content was assessed using the micro-diffusion method [15]. A $5 \mathrm{~g}$ of sample was homogenized with $45 \mathrm{~mL}$ of distilled water for $2 \mathrm{~min}$ at $8,000 \mathrm{rpm}$ and then filtered through filter pater Whatman No. 1 (What- man International, UK). One milliliter of the filtered sample solution and $1 \mathrm{~mL}$ of $\mathrm{K}_{2} \mathrm{CO}_{3}$ solution were placed on the outer section of a Conway micro-diffusion cell. One milliliter of $0.01 \mathrm{~N} \mathrm{H}_{3} \mathrm{BO}_{3}$ and $50 \mu \mathrm{L}$ of indicator $(0.066 \%$ methyl red in ethanol: $0.066 \%$ bromocresol green in ethanol $=1: 1$ ) were placed on the inner section. Cells were incubated for $90 \mathrm{~min}$ at $37^{\circ} \mathrm{C}$ and then titrated with $0.02 \mathrm{~N} \mathrm{H}_{2} \mathrm{SO}_{4}$ solution until a faint reddish color was produced.

\section{Residual nitrite level}

According to the Diazo coupling method [10], residual nitrite level was determined. A $10 \mathrm{~g}$ of cured pork loin was blended with $150 \mathrm{~mL}$ pre-heated distilled water for $2 \mathrm{~min}$. Before heating in a water bath at $80^{\circ} \mathrm{C}, 10 \mathrm{~mL} 0.5 \mathrm{~N}$ sodium hydroxide and $10 \mathrm{~mL} 12 \%$ ammonium thiosulfate were added into the blended solution. After cooling, $20 \mathrm{~mL}$ ammonium acetate buffer was added in the solution. The solution was then filled up to $200 \mathrm{~mL}$ with distilled water. After $10 \mathrm{~min}$ at room temperature, the sample was filtered through filter pater Whatman No. 1 (Whatman International, UK). A $1 \mathrm{~mL}$ of sulphanilamide solution, $1 \mathrm{~mL} \mathrm{~N}$-(1-naphyhyl) ethylenediamine dihydrochloride reagent and $3 \mathrm{~mL}$ distilled water were added into $20 \mathrm{~mL}$ filtered solution. After $20 \mathrm{~min}$ at room temperature, the absorbance value at wavelength of $540 \mathrm{~nm}$ was read in a UV/VIS spectrophotometer (Optizen 2120 UV plus, Mecasys Co. Ltd., Korea). The residual nitrite content was calculated from the standard curve of nitrite solution.

\section{Warner-Bratzler shear force}

Cooked samples used for the measurement of cooking loss were measured with a texture analyzer (TA-XT2 $i$, Stable Micro Systems Ltd., Godalming, UK) using Warner-Bratzler shear attachment (V-type blade set). Prior to analysis, samples were prepared by sampling device into $1.5 \times 1.5 \times 5 \mathrm{~cm}$ (height $\times$ width $\times$ length) in the muscle fiber direction. Test speeds were set at $2 \mathrm{~mm} / \mathrm{s}$. Data were collected and analyzed from the maximum force required to shear force through each sample [16].

\section{Sensory evaluation}

A trained ten-member panel consisting of researchers from the Department of Food Sciences and Biotechnology of Animal Resources at Konkuk University in Korea evaluated cured pork loins. Each treatment was evaluated in terms of interior color, flavor, off-flavor, chewiness, juiciness, and overall acceptability. Cured pork loin sample was cooked at $75^{\circ} \mathrm{C}$ for $30 \mathrm{~min}$, cooled at room temperature for $30 \mathrm{~min}$, and served randomly to the panelists. Sensory evaluations were performed under fluorescent lighting. Panelists were instructed to cleanse their palates between samples using water. Each sensory traits (interior color, flavor, off-flavor, chewiness, juiciness, and overall acceptability) were evaluated using a 9-point descrip- 
tive scale ( 1 = very undesirable, 9 = very desirable). Analysis was conducted using the descrptive test described by BergaraAlmeida and da Silva [17].

\section{Statistical analysis}

The statistical analysis of all data was performed by IBM SPSS Ver. 20.0 (IBM, North Castle, NY, USA). The one-way analysis of variance and Duncan's multiple range tests were used to find the differences among treatments $(\mathrm{p}<0.05)$. All means values were obtained from independent triple tests for each trait.

\section{RESULTS AND DISCUSSION}

\section{$\mathrm{pH}$, cooking loss, and moisture content}

The $\mathrm{pH}$, cooking loss, and moisture content of cured pork loin with natural nitrite source from Swiss chard and sodium nitrite are summarized in Table 2. The $\mathrm{pH}$ values of raw and cooked cured pork loins were decreased with increasing addition level of fermented Swiss chard solution $(\mathrm{p}<0.05)$. Kim et al [18] reported similar result that $\mathrm{pH}$ of cured meat with fermented spinach extract had lower $\mathrm{pH}$ values than cured meat with nitrite. Low $\mathrm{pH}$ value of fermented Swiss chard ( $\mathrm{pH}$ 5.24) might result in the low $\mathrm{pH}$ of cured meat raw and cooked. The acidic $\mathrm{pH}$ of brine and cured meat plays an important role in enhancing the cured color formation, flavor and antimicrobial activity of cured meat because nitrite can be easily reduced to nitric oxide on acidic $\mathrm{pH}$ state [19]. Therefore, the decreasing $\mathrm{pH}$ value by fermented Swiss chard might have a positive effect on the quality characteristics of cured meat.

It was hypothesized that low $\mathrm{pH}$ of final product might have negative effect on cooking loss and moisture content. Although cooking loss of cured pork loins was not significantly different from each other ( $p>0.05)$, moisture content of cured meat was decreased significantly with increasing level of FSC in brine $(\mathrm{p}<0.05)$. It has been reported that myofibrils with higher $\mathrm{pH}$ value has higher moisture content than those with lower $\mathrm{pH}$ values because of the net charge on myofibrils affected by $\mathrm{pH}$ of meat $[20,21]$. Cooking loss can be affected by various causes such as salt, additives, size, shape and composition of cured meat [22]. However, no significant difference was observed between treatments ( $p>0.05$ ). Krause et al [23] reported similar result that there is no significant difference in cooking yield of cured ham added with nitrite or pre-converted vegetable juice.

\section{Color and curing efficiency}

Table 3 provides the lightness (CIE $\mathrm{L}^{\star}$-value), redness (CIE $\mathrm{a}^{*}$-value), and yellowness (CIE $\mathrm{b}^{*}$-value) of the internal surface of raw and cooked cured meat. In general, cured meat has bright red color due to NO-myoglobin and nitrosohemochrome formed by nitric oxide with myoglobin on raw and cooked $[2,24]$. The internal surface color of raw cured meat was significantly different $(\mathrm{p}<0.05)$. Kim et al [18] reported similar result that redness value of cured meat with fermented spinach extract was increased with increasing level of fermented spinach extract. The redness values of control with $0.012 \%$ sodium nitrite and T4 were not significantly different $(\mathrm{p}>0.05)$ and redness value of $\mathrm{T} 1$ was lower than that of $\mathrm{T} 4(\mathrm{p}<0.05)$. However, the redness of some treatments (T2 and T3) was not significantly different with negative control (NC) $(\mathrm{p}>0.05)$ and $\mathrm{T} 1$ has significantly lower redness value $(\mathrm{p}<0.05)$ compared with NC. It might be a deficient nitrite content in brine of treatment and typical color of FSC. While FSC permeated into pork loin in the curing process, yellowness values of raw treatments were increased and the lightness values decreased due to the color of FSC (CIE L* value, 14.05; CIE a ${ }^{*}$-value, 2.03; CIE $\mathrm{b}^{*}$-value, 6.98). After cooking, the redness values of cured meat with FSC were increased with increasing level of FSC. The redness value of T4 was higher than that of positive control (PC) $(\mathrm{p}<0.05)$ and T3 was not significantly different compared with PC $(\mathrm{p}>0.05)$ because of the pinkish color of heat stable nitrosohemochrome formed after cooking. Sindelar et al [25] reported similar result that there was no significant difference in redness value between vegetable powder cured treatment and nitrite added control. This result demonstrated that FSC can be used as substitution of nitrite to form pinkish color of cooked cured

Table 2. The pH value, cooking loss and moisture content of cured pork loin with natural nitrite source from fermented Swiss chard (FSC)

\begin{tabular}{|c|c|c|c|c|c|c|}
\hline \multirow{2}{*}{ Traits } & \multicolumn{6}{|c|}{ Treatments ${ }^{1)}$} \\
\hline & $P C$ & NC & $\mathrm{T} 1$ & $\mathrm{~T} 2$ & T3 & $\mathrm{T} 4$ \\
\hline \multicolumn{7}{|l|}{$\mathrm{pH}$ value } \\
\hline Raw & $5.81 \pm 0.01^{\mathrm{a}}$ & $5.81 \pm 0.02^{\mathrm{a}}$ & $5.81 \pm 0.01^{\mathrm{a}}$ & $5.80 \pm 0.01^{b c}$ & $5.79 \pm 0.01^{b c}$ & $5.74 \pm 0.01$ \\
\hline Cooked & $6.08 \pm 0.02^{a}$ & $5.97 \pm 0.03^{b}$ & $6.08 \pm 0.01^{\mathrm{a}}$ & $5.98 \pm 0.01^{b}$ & $5.97 \pm 0.02^{b}$ & $5.94 \pm 0.02$ \\
\hline Cooking loss (\%) & $24.55 \pm 1.74$ & $24.65 \pm 2.04$ & $25.92 \pm 3.27$ & $25.96 \pm 3.16$ & $25.74 \pm 1.75$ & $25.02 \pm 2.32$ \\
\hline Moisture content (\%) & $68.24 \pm 0.63^{\mathrm{a}}$ & $68.08 \pm 0.30^{\mathrm{a}}$ & $67.01 \pm 0.47^{\mathrm{ab}}$ & $67.11 \pm 0.46^{\mathrm{ab}}$ & $66.22 \pm 0.16^{\mathrm{bc}}$ & $65.43 \pm 1.37$ \\
\hline
\end{tabular}

\footnotetext{
1) PC, positive control, 120 ppm nitrite; NC, negative control, nitrite-free; T1, FSC solution:water = 10:30; T2, FSC solution:water = 20:20; T3, FSC solution:water = 30:10; T4, FSC solution:water $=40: 0$.

${ }^{a-c}$ Means within a row with different letters are significantly different $(p<0.05)$.
} 
Table 3. Color characteristics and curing efficiency of cured pork loin with natural nitrite source from fermented Swiss chard (FSC)

\begin{tabular}{|c|c|c|c|c|c|c|}
\hline \multirow{2}{*}{ Traits } & \multicolumn{6}{|c|}{ Treatments $^{1)}$} \\
\hline & PC & NC & $\mathrm{T} 1$ & $\mathrm{~T} 2$ & T3 & $\mathrm{T} 4$ \\
\hline \multicolumn{7}{|l|}{ Raw } \\
\hline$L^{*}$ & $51.77 \pm 1.52^{b}$ & $63.96 \pm 0.83^{\mathrm{a}}$ & $44.73 \pm 1.52^{d}$ & $36.22 \pm 1.05^{e}$ & $38.27 \pm 0.69^{d}$ & $33.60 \pm 0.48^{f}$ \\
\hline$a^{*}$ & $8.60 \pm 0.84^{a}$ & $6.11 \pm 0.64^{b}$ & $5.56 \pm 0.67^{c}$ & $6.80 \pm 0.62^{b}$ & $6.49 \pm 0.27^{b}$ & $8.37 \pm 0.22$ \\
\hline$b^{*}$ & $4.88 \pm 0.79^{c}$ & $1.82 \pm 0.50^{\mathrm{e}}$ & $4.65 \pm 1.48^{c}$ & $3.32 \pm 0.32^{d}$ & $6.97 \pm 0.96^{b}$ & $9.56 \pm 0.90^{\circ}$ \\
\hline \multicolumn{7}{|l|}{ Cooked } \\
\hline$L^{*}$ & $72.50 \pm 0.48^{b}$ & $69.76 \pm 0.24^{c}$ & $74.91 \pm 0.33^{\mathrm{a}}$ & $68.71 \pm 0.54^{d}$ & $68.58 \pm 0.48^{d}$ & $66.71 \pm 0.35$ \\
\hline$a^{*}$ & $8.47 \pm 0.33^{b}$ & $5.80 \pm 0.14^{c}$ & $5.26 \pm 0.27^{d}$ & $5.32 \pm 0.30^{d}$ & $8.62 \pm 0.05^{b}$ & $9.08 \pm 0.48$ \\
\hline$b^{*}$ & $5.55 \pm 0.07^{e}$ & $7.89 \pm 0.20^{c}$ & $8.42 \pm 0.25^{b}$ & $8.88 \pm 0.15^{a}$ & $8.04 \pm 0.10^{c}$ & $7.30 \pm 0.14$ \\
\hline Curing pigment (ppm) & $33.93 \pm 3.94^{b}$ & $19.65 \pm 1.66^{c}$ & $20.16 \pm 0.77^{c}$ & $18.85 \pm 1.97^{c}$ & $31.97 \pm 1.16^{b}$ & $40.46 \pm 3.99^{\circ}$ \\
\hline Total pigment (ppm) & $39.44 \pm 0.79^{b}$ & $37.06 \pm 1.18^{c}$ & $32.47 \pm 0.65^{e}$ & $28.90 \pm 0.39^{f}$ & $35.70 \pm 1.17^{d}$ & $44.88 \pm 0.96^{\circ}$ \\
\hline Curing efficiency (\%) & $86.03 \pm 9.81^{a}$ & $53.07 \pm 4.98^{c}$ & $62.09 \pm 2.57^{b c}$ & $65.24 \pm 6.99^{b}$ & $89.56 \pm 1.19^{a}$ & $90.19 \pm 9.41^{\circ}$ \\
\hline
\end{tabular}

1) PC, positive control, 120 ppm nitrite; NC, negative control, nitrite-free; T1, FSC solution:water = 10:30; T2, FSC solution:water = 20:20; T3, FSC solution:water = 30:10; T4, FSC solution:water $=40: 0$.

${ }^{a-f}$ Means within a row with different letters are significantly different $(p<0.05)$.

meat. However, T1 and T2 had lower redness than $\mathrm{NC}(\mathrm{p}<$ 0.05 ) because of the deficient nitrite content for the development of cured color pigment and the distinct color of FSC. Krause et al [23] reported that nitrite cured control had higher redness value than pre-converted vegetable juice powder cured treatment. In the natural curing, the incubation condition such as vegetable concentration and temperature are important for the conversion of nitrate to nitrite to develop the redness of cured meat [26]. Therefore, T3 and T4 were suitable for substitution of curing color enhancer.

Curing pigment, total pigment, and curing efficiency was shown in Table 3 . There were significantly different by addition level of FSC and nitrite concentration. T4 had the highest value in curing pigment and curing efficiency $(\mathrm{p}<0.05)$ and curing pigment concentration was decreased with decrease level of FSC. The NC had the lowest value in curing pigment and curing efficiency $(\mathrm{p}<0.05)$. However, significant difference was not observed between $\mathrm{NC}$ and $\mathrm{T} 1$ in curing pigment and curing efficiency $(p>0.05)$. Low nitrite concentration of $\mathrm{T} 1$ might lead this result that deficient curing pigment formed and $\mathrm{T} 2$ also had no significant difference between NC in curing pigment $(\mathrm{p}>0.05)$. $\mathrm{T} 3 \mathrm{had}$ a higher curing pigment than $\mathrm{NC}(\mathrm{p}<0.05)$ and there were no significant different between curing pigment of $\mathrm{PC}$ and $\mathrm{T} 3$ ( $\mathrm{p}>0.05)$. According to Terns et al [26], total pigment concentration depended on differences of raw materials. Therefore, curing efficiency might be a useful index of cured color fading because concentration can be differed by characteristics of materials. In general, the curing efficiency of well cured meat excess $80 \%$ [27]. In this study, PC, T3, and T4 had a high curing efficiency that excessed $80 \%$ and when compared with redness value and curing efficiency, the tendency of redness and curing efficiency was similar.

\section{Thiobarbituric acid reactive substances and volatile basic nitrogen}

Figure 1 provides TBARS and VBN values of cooked cured pork loins. PC had the lowest TBARS and VBN values among all treatments $(\mathrm{p}<0.05)$. Choi et al [28] reported that lipid oxidation can affect the quality characteristics of meat products such as color, flavor, and nutritious value. With increasing levels of FSC, there was a decreasing tendency in TBARS value $(p<0.05)$ because the amount of nitrite of FSC was increased. Sindelar et al [25] reported that natural nitrite from vegetable powder worked as an antioxidant. Tsoukalas et al [29] also reported that vegetable powder has antioxidant activity equivalent to nitrite. They reported that fermented sausage containing freeze-dried leek powder had similar TBARS value to that of the control containing $150 \mathrm{ppm}$ nitrite. Furthermore, the antioxidant capacity of Swiss chard might inhibit lipid oxidation of cured meat. Ninfali and Angelion [8] reported that Swiss chard has abundant vitamins, phenols, and flavonoids that can prevent lipid oxidation.

Meat protein can be decomposed by some enzymes and microorganisms during the storage period. Protein deterioration could be indicated by VBN content [15]. The VBN content of cured meat with FSC was higher than that of PC or NC ( $<<0.05)$. Kim et al [18] reported similar result that the VBN values cured meat with fermented spinach solution was higher than cured meat with nitrite. This result might be caused by starter culture in FSC.

\section{Residual nitrite content}

Residual nitrite content of cooked cured pork loin is presented in Figure 2. Residual nitrite contents of cured pork loin were significantly different among all treatment $(\mathrm{p}<0.05)$. According to Kim et al [18], residual nitrite content of cured meat with fermented spinach was lower than that of cured meat 


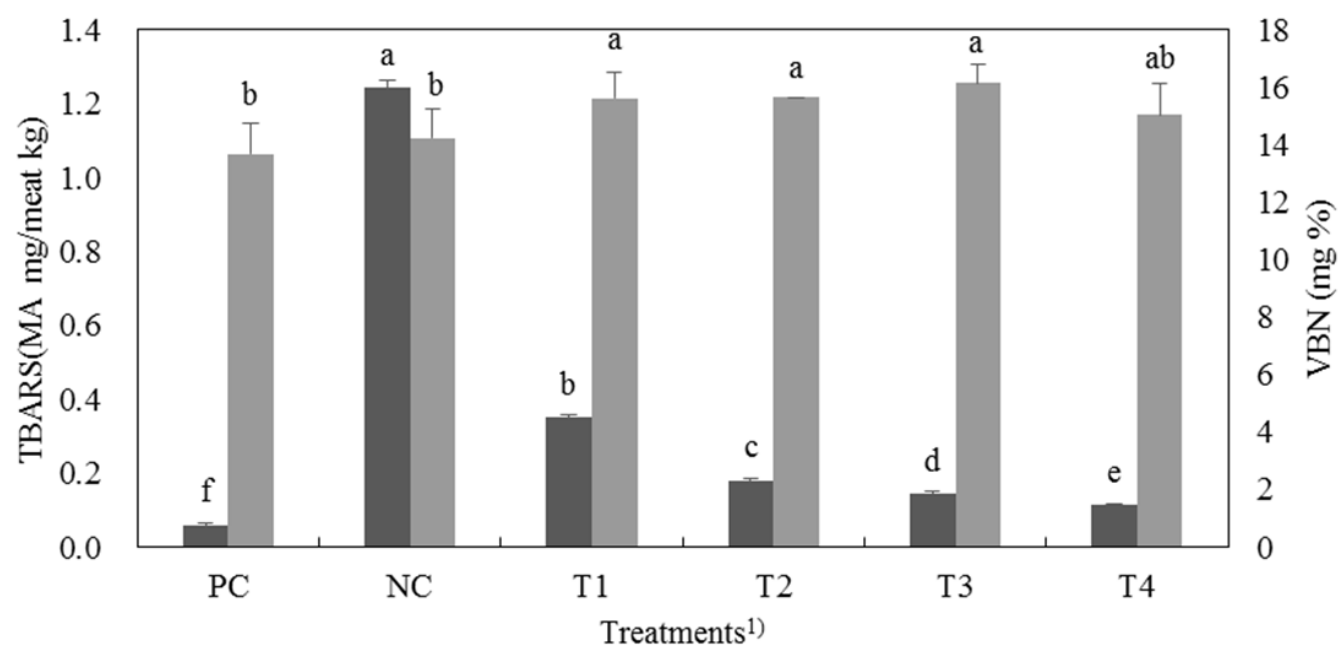

Figure 1. TBARS $(\square)$ and VBN $(\square)$ values of cured pork loin with natural nitrite source from FSC. TBARS, Thiobarbituric acid reactive substances; VBN, volatile basic nitrogen; FSC, fermented Swiss chard; MDA, malondialdehyde. ") PC, positive control, 120 ppm nitrite; NC, negative control, nitrite-free; T1, FSC solution:water = 10:30; T2, FSC solution:water $=20: 20 ;$ T3, FSC solution:water $=30: 10 ;$ T4, FSC solution:water $=40: 0{ }^{\text {aff }}$ Different letters on top of the column mean significant difference between treatments $p<0.05)$.

with sodium nitrite. Residual nitrite content of cured meat with FSC also was lower than that of PC. Acidic pH and abundant antioxidant during curing process can increase the rate of curing color formation and decrease residual nitrite content because the acidic $\mathrm{pH}$ state and antioxidant such as phenols and flavonoids in meat and meat products can easily deplete nitrite to nitric oxide [29-32]. Therefore, the low $\mathrm{pH}$ and antioxidant components of FSC might deplete nitrite in cured meat containing FSC, whereas PC had highest residual nitrite content because it has higher $\mathrm{pH}$ value than the others $(\mathrm{p}<0.05)$. In general, residual nitrite content of cooked meat is decreased about $65 \%$ during the heating [2]. Because the combination of heat, acidic $\mathrm{pH}$, and antioxidant depleted ni- trite in FSC treatment, treatments with FSC had lower residual nitrite levels less than PC.

\section{Warner-Bratzler shear force}

Figure 3 provides Warner-Bratzler shear force (WBSF) values of cooked cured pork loins. WBSF values of cooked pork loin were significantly different $(\mathrm{p}<0.05)$. T4 showed the highest WBSF value among all treatments while $\mathrm{T} 1 \mathrm{had}$ the lowest WBSF value $(\mathrm{p}<0.05)$. The Shear force and $\mathrm{pH}$ value of meat are generally in inverse proportion [17]. Ruiz-Ramírez et al [33] showed that low $\mathrm{pH}$ cured meat had higher hardness value than the high $\mathrm{pH}$ cured meat. In general, $\mathrm{pH}$ of meat affected net charge of meat and structure. Meat with higher

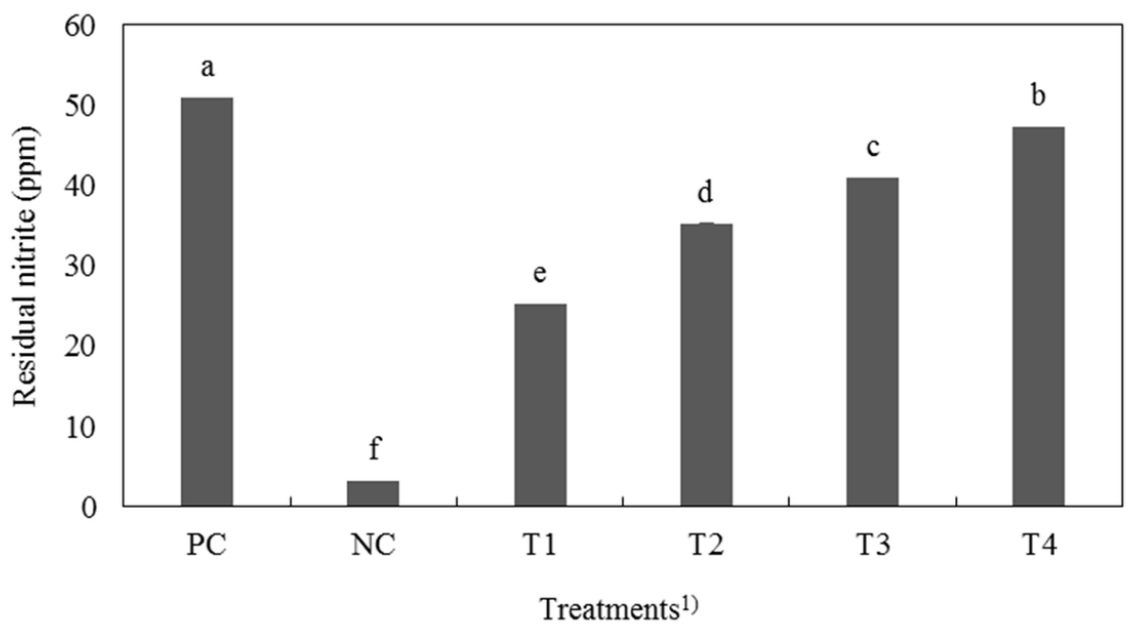

Figure 2. Residual nitrite contents of cured pork loin with natural nitrite source from fermented Swiss chard (FSC). ${ }^{1)}$ PC, positive control, 120 ppm nitrite; NC, negative control, nitrite-free; T1, FSC solution:water = 10:30; T2, FSC solution:water = 20:20; T3, FSC solution:water = 30:10; T4, FSC solution: water $=40: 0$. ${ }^{\text {aff }}$ Different letters on top of the column mean significant difference between treatments $(p<0.05)$. 


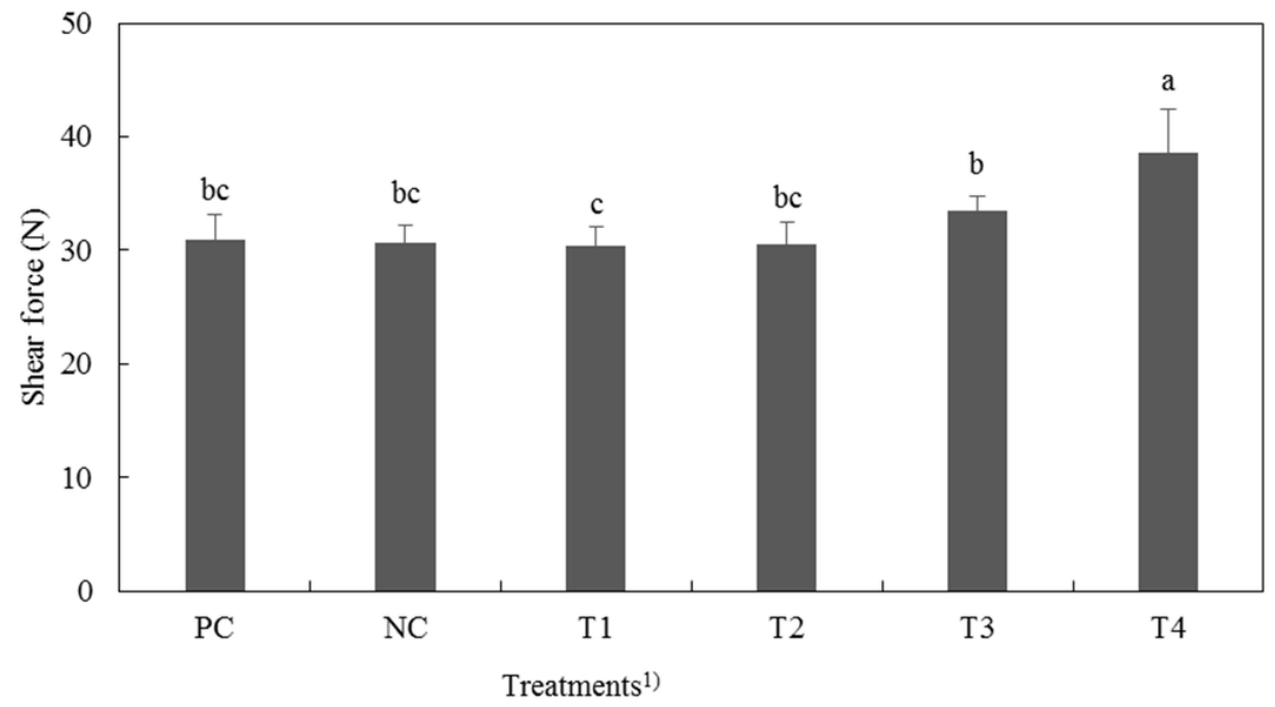

Figure 3. Warner-Bratzler Shear force contents of cured pork loin with natural nitrite source from fermented Swiss chard (FSC). .' PC, positive control, 120 ppm nitrite; NC, negative control, nitrite-free; T1, FSC solution:water = 10:30; T2, FSC solution:water = 20:20; T3, FSC solution:water = 30:10; T4, FSC solution:water $=40: 0$. ${ }^{\text {acc }}$ Different letters on top of the column mean significant difference between treatments $(p<0.05)$.

$\mathrm{pH}$ has higher moisture content than lower $\mathrm{pH}$ meat. According to Barlocco et al [34], moisture content and WBSF of pork muscle had negative correlations. Therefore, the lower the $\mathrm{pH}$ treatment had, the higher the value of WBSF $(\mathrm{p}<0.05)$.

\section{Sensory evaluation}

Table 4 presented the evaluation score of the cured pork loin in sensory test. Sensory scores for flavor, off-flavor, chewiness, juiciness, and overall acceptability were not significantly different among all treatments $(\mathrm{p}>0.05)$. In instrumental measurement, shear force and moisture contents had different values among each treatment. However, chewiness and juiciness were no significantly different in sensory evaluation. There was no significant difference in color intensity among NC, T1, T2, and T3 ( $\mathrm{p}>0.05)$, whereas the score for reddish color of $\mathrm{PC}$ and $\mathrm{T} 4$ were higher than other treatments $(\mathrm{p}<0.05)$. Sindelar et al [25] reported that the characteristic aroma of vegetable juice would have negative impact on meat. Tsoukalas et al [29] also reported that lower vegetable level in meat product had higher sensory scores for flavor. In this study, no significant difference was found in the overall acceptability and flavor among all treatments ( $\mathrm{p}>0.05)$. This means that the color and flavor of FSC had no significant impact on the overall acceptability of cured pork loin containing FSC.

\section{CONCLUSION}

In conclusions, quality characteristics of cured pork loin with natural nitrite source from Swiss chard were investigated in this. When the addition level of FSC was increased, the redness value of cured meat was increased and lipid oxidation was decreased. Residual nitrite contents of cured pork loins containing FSC were much lower than nitrite added treat-

Table 4. Sensory properties of cured pork loin with natural nitrite source from fermented Swiss chard (FSC)

\begin{tabular}{|c|c|c|c|c|c|c|}
\hline \multirow{2}{*}{ Traits } & \multicolumn{6}{|c|}{ Treatments $^{1)}$} \\
\hline & PC & NC & $\mathrm{T} 1$ & $\mathrm{~T} 2$ & T3 & $\mathrm{T} 4$ \\
\hline Color & $8.25 \pm 0.96^{a}$ & $6.00 \pm 0.82^{c}$ & $6.25 \pm 0.50^{c}$ & $6.75 \pm 1.26^{\mathrm{bc}}$ & $6.75 \pm 0.5^{b c}$ & $7.75 \pm 0.5^{\mathrm{ab}}$ \\
\hline Flavor & $7.50 \pm 1.05$ & $7.00 \pm 0.89$ & $6.50 \pm 1.22$ & $6.50 \pm 0.55$ & $6.67 \pm 1.03$ & $6.33 \pm 1.03$ \\
\hline Off flavor & $7.50 \pm 1.05$ & $6.33 \pm 1.37$ & $6.83 \pm 1.33$ & $6.67 \pm 0.82$ & $7.00 \pm 0.89$ & $6.50 \pm 1.05$ \\
\hline Chewiness & $7.33 \pm 0.52$ & $7.17 \pm 0.75$ & $7.00 \pm 1.26$ & $6.83 \pm 0.75$ & $7.17 \pm 0.98$ & $7.17 \pm 0.75$ \\
\hline Juiciness & $7.17 \pm 0.41$ & $6.67 \pm 0.82$ & $6.67 \pm 1.37$ & $6.67 \pm 0.52$ & $6.67 \pm 0.52$ & $6.50 \pm 0.84$ \\
\hline Overall acceptability & $7.50 \pm 0.84$ & $6.17 \pm 0.41$ & $6.67 \pm 1.21$ & $6.40 \pm 0.55$ & $6.83 \pm 0.98$ & $6.83 \pm 0.75$ \\
\hline
\end{tabular}

9-point descriptive scale ( 1 = very undesirable, $9=$ very desirable) was used for sensory evaluation

1) PC, positive control, 120 ppm nitrite; NC, negative control, nitrite-free; T1, FSC solution:water = 10:30; T2, FSC solution:water = 20:20; T3, FSC solution:water = 30:10;

T4, FSC solution:water $=$ 40:0.

${ }^{a-c}$ Means within a row with different letters are significantly different $(p<0.05)$. 
ment. Furthermore, the addition of FSC did not have any impact on overall acceptability. Hence, pre-converted Swiss chard could be used as natural curing agent for cured pork loin and substitute synthetic nitrite.

\section{CONFLICT OF INTEREST}

We certify that there is no conflict of interest with any financial organization regarding the material discussed in the manuscript.

\section{ACKNOWLEDGMENTS}

This research was supported the Main Research Program (E0145100-06) by the Korean Food Research Institute (KFRI) funded by the Ministry of Science and ICT. This research was also partially supported by the Agri-Bio Industry Technology Development Program (317001-3) by the Ministry of Agriculture, Food and Rural Affairs (Republic of Korea).

\section{REFERENCES}

1. Choi YS, Kim TK, Jeon KH, et al. Effects of pre-converted nitrite from red beet and ascorbic acid on quality characteristics in meat emulsions. Korean J Food Sci Anim Resour 2017;37: 288-96. https://doi.org/10.5851/kosfa.2017.37.2.288

2. Kim TK, Lee MA, Sung JM, Jeon KH, Kim YB, Choi YS. Combination effects of nitrite from fermented spinach and sodium nitrite on quality characteristics of cured pork loin. AsianAustralas J Anim Sci 2019;32:1603-10. https://doi.org/10.5713/ ajas. 18.0903

3. Seong PN, Ba HV, Kim YS, et al. Effects of additions of Monascus and Laccaic acid on the color and quality properties of nitrite-free emulsion sausage during refrigerated storage. Korean J Food Sci Anim Resour 2017;37:10-7. https://doi. org/10.5851/kosfa.2017.37.1.10

4. Hwang KE, Kim TK, Kim HW, et al. Effect of natural preconverted nitrite sources on color development in raw and cooked pork sausage. Asian-Australas J Anim Sci 2018;31: 1358-65. https://doi.org/10.5713/ajas.17.0767

5. Sebranek JG, Jackson-Davis AL, Myers KL, Lavieri NA. Beyond celery and starter culture: Advances in natural/organic curing processes in the United States. Meat Sci 2012;92:267-73. https:// doi.org/10.1016/j.meatsci.2012.03.002

6. Ballmer-Weber BK, Hoffmann A, Wüthrich1 B, et al. Influence of food processing on the allergenicity of celery: DBPCFC with celery spice and cooked celery in patients with celery allergy. Allergy 2002;57:228-35. https://doi.org/10.1034/j.1398-9995. 2002.103319.x

7. Shin DM, Hwang KE, Lee CW, Kim TK, Park YS, Han SG. Effect of Swiss chard (Beta vulgaris var. cicla) as nitrite replacement on color stability and shelf-life of cooked pork patties during refrigerated storage. Korean J Food Sci Anim Resour 2017;37:418-28.

8. Ninfali P, Angelino D. Nutritional and functional potential of Beta vulgaris cicla and rubra. Fitoterapia 2013;89:188-99. https://doi.org/10.1016/j.fitote.2013.06.004

9. González MCM, Martínez-Tomé MJ. Isasa MET. Nitrate and nitrite content in organically cultivated vegetables. Food Addi Contam Part B Surveill 2010;3:19-29. https://doi.org/10.1080/ 19440040903586299

10. Korea Food and Drug Administration (KFDA). Cheongju, Korea: Korean Food Standards, Anlytical methods of residual nitrite in foods; 2016. pp. 10.2.25-6.

11.Hernández P, Navarro JL, Toldrá F. Lipolytic and oxidative changes in two Spanish pork loin products: dry-cured loin and pickled-cured loin. Meat Sci 1999;51:123-8. https://doi. org/10.1016/S0309-1740(98)00108-9

12. AOAC. Official methods of analysis of AOAC, Vol. 41. 17th ed. Association of Official Analytical Chemists. Washington DC, USA: AOAC International; 2000.

13. Hornsey HC. The colour of cooked cured pork. I.-Estimation of the Nitric oxide-Haem Pigments. J Sci Food Agric 1956;7: 534-40. https://doi.org/10.1002/jsfa.2740070804

14. Tarladgis BG, Watts BM, Younthan MT, Dugan L. A distillation method for the quantitative determination of malonaldehyde in rancid foods. J Am Oil Chem Soc 1960;37:44-8. https:// doi.org/10.1007/BF02630824

15. Pearson D. Apllication of chemical methods for the assessment of beef quality. II. Methods related to protein breakdown. J Sci Food Agric 1968;19:366-9. https://doi.org/10.1002/jsfa. 2740190703

16. Combes S, Lepetit J, Darche B, Lebas F. Effect of cooking temperature and cooking time on Warner-Bratzler tenderness measurement and collagen content in rabbit meat. Meat Sci 2004;66:91-6. https://doi.org/10.1016/S0309-1740(03)00019-6

17. Bergara-Almeida S, da Silva MAAP. Hedonic scale with reference: Performance in obtaining predictive models. Food Qual Prefer 2002;13:57-64. https://doi.org/10.1016/S0950-3293(01) 00057-X

18. Kim TK, Kim YB, Jeon KH, et al. Effect of fermented spinach as sources of pre-converted nitrite on color development of cured pork loin. Korean J Food Sci Anim Resour 2017;37:10513. https://doi.org/10.5851/kosfa.2017.37.1.105

19. Guerrero L, Gou P, Arnau J. The influence of meat $\mathrm{pH}$ on mechanical and sensory textural properties of dry-cured ham. Meat Sci 1999;52:267-73. https://doi.org/10.1016/S0309-1740 (98)00175-2

20.Hamm R. Functional properties of the myofibrillar system and their measurements. In: Muscle as food. Bechtel PJ, editor. NY, USA: Academic Press; 1986. pp. 135-99.

21. Kim HY, Lee ES, Jeong JY, et al. Effect of bamboo salt on the physicochemical properties of meat emulsion systems. Meat Sci 2010;86:960-5. https://doi.org/10.1016/j.meatsci.2010. 
08.001

22. Choi YS, Choi JH, Han DJ, et al. Characteristics of low-fat meat emulsion systems with pork fat replaced by vegetable oils and rice bran fiber. Meat Sci 2009;82:266-71. https://doi.org/10. 1016/j.meatsci.2009.01.019

23. Krause BL, Sebranek JG, Rust RE, Mendonca A. Incubation of curing brines for the production of ready-to-eat, uncured no-nitrite-or-nitrate-added, ground, cooked and sliced ham. Meat Sci 2011;89:507-13. https://doi.org/10.1016/j.meatsci. 2011.05.018

24. Killday KB, Tempesta MS, Bailey ME, Metral CJ. Structural characterization of nitrosylhemochromogen of cooked cured meat: implications in the meat-curing reaction. J Agric Food Chem 1988;36:909-14. https://doi.org/10.1021/ jf00083a006

25. Sindelar JJ, Cordray JC, Sebranek JG, Love JA, Ahn DU. Effects of varying levels of vegetable juice powder and incubation time on color, residual nitrate and nitrite, pigment, $\mathrm{pH}$, and trained sensory attributes of ready-to-eat uncured ham. J Food Sci 2007;72:S388-95. https://doi.org/10.1111/j.1750-3841.2007. 00404.x

26. Terns MJ, Milkowski AL, Rankin SA, Sindelar JJ. Determining the impact of varying levels of cherry powder and starter culture on quality and sensory attributes of indirectly cured, emulsified cooked sausages. Meat Sci 2011;88:311-8. https:// doi.org/10.1016/j.meatsci.2011.01.009

27. Pearson AM, Tauber FW. Processed Meats: Analytical methods. 2nd ed. Westport, CT, USA: AVI Publishing; 1984. p. 360-1.

28. Choi YS, Choi JH, Kim HY, et al. Effect of lotus (Nelumbo nucifera) leaf powder on the quality characteristics of chicken patties in refrigerated storage. Korean J Food Sci Anim Resour 2011;31:9-18. https://doi.org/10.5851/kosfa.2011.31.1.009

29. Tsoukalas DS, Katsanidis E, Marantidou S, Bloukas JG. Effect of freeze-dried leek powder (FDLP) and nitrite level on processing and quality characteristics of fermented sausages. Meat Sci 2011;87:140-5. https://doi.org/10.1016/j.meatsci.2010. 10.003

30.Kim TK, Hwang KE, Lee MA, Paik HD, Kim YB, Choi YS. Quality characteristics of pork loin cured with green nitrite source and some organic acids. Meat Sci 2019;152:141-5. https://doi.org/10.1016/j.meatsci.2019.02.015

31. Hwang KE, Kim HW, Song DH, et al. Application of Ganghwa Mugwort in combination with ascorbic acid for the reduction of residual nitrite in pork sausage during refrigerated storage. Korean J Food Sci Anim Resour 2014;34:178-84. https://doi. org/10.5851/kosfa.2014.34.2.178

32. Bae SM, Cho MG, Hong GT, Jeong JY. Effect of NaCl concentration and cooking temperature on the color and pigment characteristics of presalted ground chicken breasts. Korean J Food Sci Anim Resour 2018;38:417-30. https://doi.org/10. 5851/kosfa.2018.38.2.417

33. Ruiz-Ramírez J, Arnau J, Serra X, Gou P. Relationship between water content, $\mathrm{NaCl}$ content, $\mathrm{pH}$ and texture parameters in dry-cured muscles. Meat Sci. 2005;70:579-87. https:/doi.org/ 10.1016/j.meatsci.2005.02.007

34. Barlocco N, Vadell A, Ballesteros F, Galietta G, Cozollino D. Predicting intramuscular fat, moisture and Warner-Bratzler shear force in pork muscle using near infrared reflectance spectroscopy. Anim Sci 2006;82:111-6. https://doi.org/10.1079/ ASC20055 